Correspondence will be sent to Dr. Chao Liang

Email: cliang823@gmail.com

Tel: 86-18809873156 (Cell); 1-86-24-83978667 (office); Fax: 1-86-24-83970376

Key Laboratory of Forest Ecology and Management

Institute of Applied Ecology, Chinese Academy of Sciences

Shenyang, 110016 P.R. China

\title{
Impacts of vegetation type and climatic zone on neutral sugar distribution in natural forest soils
}

Lefang Cui ${ }^{\mathrm{ab}}$; Chao Liang ${ }^{\mathrm{ac}} *$; David S. Duncan ${ }^{\mathrm{c}}$; Xuelian Bao ${ }^{\mathrm{a}}$; Hongtu Xie ${ }^{\mathrm{a}}$; Hongbo He ${ }^{\mathrm{a}}$; Kyle Wickings ${ }^{\mathrm{d}} ; \quad$ Xudong Zhang ${ }^{\mathrm{a}} ;$ Fusheng Chen $^{\mathrm{e}}$

a Key Laboratory of Forest Ecology and Management, Institute of Applied Ecology, Chinese Academy of Sciences, Shenyang 110016, China

b University of Chinese Academy of Sciences, Beijing 100049, China

c Great Lakes Bioenergy Research Center, University of Wisconsin-Madison, WI 53726, USA

d Department of Entomology, Cornell University, Geneva, NY 14456, USA

e College of Forestry, Jiangxi Agricultural University, Nanchang 330045, China 


\section{Abstract}

Soil neutral sugars are a significant component of labile soil organic carbon (SOC) and are derived from both plant and microbial biomass. While plants synthesize both pentose and hexose neutral sugars, microbes almost exclusively produce hexoses. Hexose to pentose ratios in soil thus potentially indicate the extent to which microbes process labile SOC. In this study, we used the ratio of galactose + mannose $(\mathrm{G}+\mathrm{M})$ to arabinose $+\mathrm{xylose}(\mathrm{A}+\mathrm{X})$ to estimate the contribution of sugars derived from microbes and plants to SOC in forest ecosystems. We explored how forest type and climatic zone influence soil neutral sugar profiles by studying coniferous and broadleaf forests located in temperate and subtropical regions in China. At each site, neutral sugars from organic (O) and top-layer mineral (A) soil horizons, as well as from freshly-fallen leaf litter, were measured. Total SOC and soil neutral sugar contents were lower in the subtropical region than in the temperate region, with lower levels in the A horizon than in the O horizon. In both climatic zones, litter $(\mathrm{G}+\mathrm{M}) /(\mathrm{A}+\mathrm{X})$ ratios were higher in coniferous forests $(1.2 \pm 0.3)$ than in broadleaf forests $(0.4 \pm 0.1)$. Differences in the $(\mathrm{G}+\mathrm{M}) /(\mathrm{A}+\mathrm{X})$ ratios between forest types (coniferous and broadleaf) persisted in the $\mathrm{O}$ horizon $(1.4 \pm 0.2>0.9 \pm 0.0)$ and in the $\mathrm{A}$ horizon $(1.8 \pm 0.1>1.3 \pm 0.0)$. Across climate zones and forest types, ratios increased from litter over the $\mathrm{O}$ horizon to the A horizon. Contrary to our expectations, climate zone did not affect soil $(\mathrm{G}+\mathrm{M}) /(\mathrm{A}+\mathrm{X})$ ratios. Our findings emphasize the important contribution of microbial biomass to labile SOC pools while revealing that soil neutral sugar profiles do not respond to climatic zone drivers as expected.

Keywords: Soil organic carbon; temperate and subtropical zone, soil carbohydrates; sugar origin and recycling. 


\section{Introduction}

The dynamics of soil organic carbon (SOC) in terrestrial ecosystems are a key component in determining whether these systems serve as carbon (C) sources or sinks. Twice as much $\mathrm{C}$ is stored in SOC as in the atmosphere, making it the largest dynamic terrestrial C pool (Balser, 2005; Batjes, 1996). Ultimately, SOC is derived from plant primary production (Kögel-Knabner, 2002; Schlesinger and Bernhardt, 2013), but the processes governing the transformation of plant materials into SOC are still being elucidated. There is growing evidence that microbial anabolism, principally the accumulation of microbial metabolic products and necromass, plays a critical role in soil C storage (Schaeffer et al., 2015; Schimel and Schaeffer, 2012). These new findings suggest labile soil $\mathrm{C}$, which is the dominant $\mathrm{C}$ and energy source for soil microorganisms (Haider, 1992; Kiem and Kögel-Knabner, 2003), could be an important determinant in the creation of stable SOC.

Neutral sugars are major components of labile SOC, typically comprising 5-25\% of total SOC, and their responses to turnover and accumulation processes are representative of labile SOC more broadly (Cheshire, 1979; Murata et al., 1999). Neutral sugar quantities can thus reflect the energy and $\mathrm{C}$ available to soil microorganisms in an ecosystem. Additionally, neutral sugar profiles are potentially informative of the extent of microbial processing of SOC (Amelung et al., 1999). Neutral sugar synthesis by soil microorganisms is heavily biased toward the non-glucose hexoses galactose $(\mathrm{G})$ and mannose $(\mathrm{M})$, as well as the deoxyhexoses rhamnose and fucose (Cheshire, 1979; Spielvogel et al., 2007). The pentose arabinose (A) and xylose (X) come almost exclusively from plant materials, although plant materials also contain hexoses (Gunina and Kuzyakov, 2015). The hexose to pentose ratio $(\mathrm{G}+\mathrm{M}) /(\mathrm{A}+\mathrm{X})$ can thus indicate the contribution of microbially-synthesized material in the soil neutral sugar pool (Oades, 1984; Schmidt et al., 2015), and more broadly the extent of microbial processing of labile soil C. Plant litter, as the principal input for SOM formation (Kögel-Knabner, 2002), can directly contribute to soil neutral sugar pools. Plant species can differ in their neutral sugar ratios (Berg and Mcclaugherty, 2008); this may be reflected in soil neutral sugar profiles, so it is 
important to consider the extent to which soil neutral sugar pools are hexose-enriched relative to their litter inputs (Gunina and Kuzyakov, 2015).

To date, most neutral sugar studies have focused on agricultural ecosystems (Puget et al., 1998; Xie et al., 2014) or on the impacts of land-use change (Guggenberger et al., 1994; Jolivet et al., 2006; Navarrete and Tsutsuki, 2008), while few have focused on natural forest systems. This represents a critical knowledge gap. Forests account for $73 \%$ of global soil C storage (Sedjo, 1993) and possess greater plant biomass than grassland or agricultural ecosystems (Schlesinger and Bernhardt, 2013). At the same time, forests are particularly susceptible to loss of soil C following land management changes such as conversion to cultivated land (Murty et al., 2002). Neutral sugar dynamics may differ between forests and other, more intensively studied systems, due to the large quantity and highly variable quality of litter inputs in forests. Thus, studying neutral sugar profiles within natural forests will improve understanding of this key component of the global $\mathrm{C}$ cycle.

In this study, we analyzed soil neutral sugar profiles from two types of forest, coniferous and broadleaf, located in temperate and subtropical climate zones in China. The two climate zones provided contrasting levels of microbial processing of SOM, with the higher temperature and rainfall expected to stimulate microbial activity and lead to greater enrichment of microbially-derived neutral sugars (Nacro et al., 2005; Navarrete and Tsutsuki, 2008). The two forest types provided different litter input signals, as hemicellulose composition differs between deciduous and coniferous species (Kögel-Knabner, 2002), particularly in their proportions of xylose and mannose (Eriksson et al., 1990). The objective of this study was to compare the soil neutral sugar profiles in climatically contrasted forest ecosystems: temperate and subtropical. We hypothesized that: 1) due to variations in neutral sugar input with litter, soil neutral sugar profiles will differ between forest types, and 2) due to higher microbial activity, soils at the subtropical site will be enriched in neutral sugars of microbial origin relative to soils at the temperate region.

\section{Material and methods}




\subsection{Site description and sampling}

Soil samples were collected from temperate-zone forests at Changbai Mountain (CBM) in Jilin Province and from subtropical-zone forests at Jiulian Mountain (JLM) in Jiangxi Province of China, respectively (Fig. 1). The CBM is frequently studied as a typical representative of temperate forest ecosystems in China (Zhu et al., 2010), located at an elevation of 740-2623.5 m, with a mean annual temperature (MAT) of $2-5^{\circ} \mathrm{C}$ and mean annual precipitation (MAP) from 500 to $900 \mathrm{~mm}$. In the north slope of $\mathrm{CBM}$, we chose a broadleaf forest $\left(\mathrm{BF}, 42^{\circ} 23^{\prime} \mathrm{N}, 128^{\circ} 05^{\prime} \mathrm{E}\right)$ and a coniferous forest $\left(\mathrm{CF}, 42^{\circ} 04^{\prime} \mathrm{N}, 128^{\circ} 14^{\prime} \mathrm{E}\right)$ in which Tilia amurensis Rupr. and Larix olgensis var. changpaiensis A. Henry were the dominant species, respectively. The JLM National Nature Reserve has been well regarded as a typical subtropical forest ecosystem in China, whose elevation is from 280 to $1430 \mathrm{~m}$, MAT is $15.9-17.4^{\circ} \mathrm{C}$ and MAP ranges from 1502 to $2469 \mathrm{~mm}$. In JLM, a broadleaf forest ecosystem $\left(24^{\circ} 32^{\prime} \mathrm{N}, 114^{\circ} 27^{\prime} \mathrm{E}\right)$ whose dominant species was Castanopsis carlesii Hemsl. and a coniferous forest $\left(24^{\circ} 36^{\prime} \mathrm{N}, 114^{\circ} 36^{\prime} \mathrm{E}\right)$ dominated by Pinus massoniana Lamb. were chosen in our study. Soils in BF and CF of CBM were classified as Cambisols, while BF and CF of JLM were Acrisols and Alisols, respectively, by World Reference Base for Soil Resources (WRB, 2014).

In each forest, we marked five plots separated by > 20 meters; within each plot, we placed five sampling sites separated by > 3 meters. At each sampling site, three soil samples were taken and separated into the organic layer ( $\mathrm{O}$ horizon) and upper mineral layer (top $10 \mathrm{~cm}$ of A horizon). Soil samples were pooled at site level, then kept at $4{ }^{\circ} \mathrm{C}$. Sampling sites within plots were selected randomly from mature stands of the dominant tree species; soil samples were collected from random midpoints between the tree trunk and the edge of vertical projection of the tree crown. After plant roots, stones and animal residues were picked out, each $\mathrm{O}$ horizon organic soil sample was homogenized and sieved to $8 \mathrm{~mm}$ and each A horizon mineral soil was homogenized and sieved to $2 \mathrm{~mm}$. Sieved soils were stored at $-20^{\circ} \mathrm{C}$ until further analysis. In the meantime, plant litters of each dominant species at the sampling sites were collected by litter traps, air-dried, ground and sieved to $0.15 \mathrm{~mm}$ for neutral 
sugar determination.

\subsection{Soil properties analyses}

Soil samples were lyophilized with an EYELA FDU-1100 Freeze Dryer (Tokyo Rikakikai Co., Japan), then a portion of the soil was ground and sieved $(<0.15 \mathrm{~mm})$ for analysis. Soil $\mathrm{pH}$ was determined at a soil to $\mathrm{CO}_{2}$-free water ratio of 1:2.5 (w/w). Dissolved organic carbon (DOC) was extracted at a soil to $\mathrm{CO}_{2}$-free water ratio 1:10 (w/w), shaken for $30 \mathrm{~min}$ at $c a .200 \mathrm{rpm}$ and filtered using a $0.45 \mu \mathrm{m}$ Millipore filter, then detected by Multi N/C 3000 (Analytik Jena, Jena, Germany). Soil total carbon (TC) and total nitrogen (TN) were determined by Element Analyzer Vario EL III (Elementar Analysensysteme GmbH, Hanau, Germany). We interpreted TC as SOC, as all soil samples had $\mathrm{pH}<7.0$.

\subsection{Neutral sugars analysis}

Neutral sugars were quantified using capillary gas chromatography (Zhang et al., 2007). Soil and litter samples containing about $4 \mathrm{mg}$ organic $\mathrm{C}$ were hydrolyzed by 4 $\mathrm{M}$ trifluoroacetic acid (TFA) at $105^{\circ} \mathrm{C}$ for $4 \mathrm{~h}$. Adonitol was added as the first internal standard. The sample solutions were filtered and the filters were washed with deionized water. Then the solutions were evaporated at $45^{\circ} \mathrm{C}$. The residue was redissolved in water and adjusted to $\mathrm{pH}$ 6.6-6.8 with potassium hydroxide and TFA; precipitates that resulted were removed by centrifugation for $10 \mathrm{~min}$ at $2000 \times \mathrm{g}$. After supernatants were evaporated at $45^{\circ} \mathrm{C}$, the residue was dissolved in deionized water and myo-inositol was added as the second internal standard, after which the sample was lyophilized for at least $8 \mathrm{~h}$. Samples were redissolved in $300 \mu \mathrm{L}$ derivatization reagent $\left(32 \mathrm{mg} \mathrm{mL} L^{-1}\right.$ hydroxylamine hydrochloride, $40 \mathrm{mg} \mathrm{mL}^{-1}$ 4-dimethylamino-pyridine in 4:1 (v/v) pyridine-methanol), with shaking and heating at $75^{\circ} \mathrm{C}$ for $30 \mathrm{~min}$. After being cooled, $1 \mathrm{~mL}$ acetic anhydride was added and the vial was shaken and heated at $75^{\circ} \mathrm{C}$ for 20 min. After this derivatization reaction, $1.5 \mathrm{~mL}$ dichloromethane was added for phase separation, and then $1 \mathrm{M}$ hydrochloric acid and

deionized water were added successively and completely removed to extract the excess derivatization reagents. The organic phase was dried at $45^{\circ} \mathrm{C}$ by $\mathrm{N}_{2}$ and dissolved in ethyl acetate-hexane (1:1, v/v). Neutral sugars in samples were 
determined using an HP 6890 capillary gas chromatograph (Agilent Technologies, DE, USA) equipped with a flame ionization detector (FID) and a DB-1 fused silica capillary column $(30 \mathrm{~m} \times 0.2 \mathrm{~mm} \times 0.25 \mu \mathrm{m})$. The temperature was set as follows: the initial column temperature of $175^{\circ} \mathrm{C}$ was held for $4 \mathrm{~min}$, increased at $4{ }^{\circ} \mathrm{C} \min ^{-1}$ to $225^{\circ} \mathrm{C}$, held for $2 \mathrm{~min}$, increased again at $50^{\circ} \mathrm{C} \mathrm{min}^{-1}$ to $300^{\circ} \mathrm{C}$, held for $2 \mathrm{~min}$. Neutral sugars were quantified relative to the internal standard adonitol. Recovery efficiency was monitored using the myo-inositol internal standard. Total neutral sugar content was calculated as the sum of the eight monosaccharides (arabinose, xylose, galactose, mannose, rhamnose, fucose, ribose and glucose) in soils.

\subsection{Statistical analyses}

Soil neutral sugar abundances were analyzed using mixed models with the SPSS statistical software package (SPSS, Inc., Chicago, IL) to evaluate the individual effects of soil horizons, forest types and climatic zones, as well as their interactions. Soil and neutral sugar traits were compared between the $\mathrm{O}$ and $\mathrm{A}$ horizons using paired $t$-tests, and between forest types and climatic zones using independent $t$-tests. The vegan package (Oksanen et al., 2015) in the R statistical environment (2015) was used to conduct redundancy analysis (RDA) between soil neutral sugar contents (normalized to SOC) and environment variables (soil horizon, forest type, climatic zone, and soil $\mathrm{pH}, \mathrm{DOC}$, and total $\mathrm{N}$ ). RDA is a constrained ordination method that models variability in variables of interest (i.e. soil neutral sugar concentrations) through constraining variables (i.e. soil environmental variables). Note that SOC was not included as a potential explanatory variable, as it was used to normalize neutral sugar contents within samples. Explanatory variables were first screened by forward selection with the packfor $\mathrm{R}$ package (Dray et al., 2013), with Monte Carlo permutation used to evaluate the significance of each variable's contribution to the model. Only variables with significant $(\mathrm{P}<0.05)$ contributions were retained. The unique variation (adjusted $\mathrm{R}^{2}$ ) explained by each variable was determined by variation partitioning (Peres-Neto et al., 2006). The ordination diagram showing the relationships between soil neutral sugar profiles and the significant factors was based 
on the RDA results.

\section{Results}

\subsection{Soil physiochemical properties}

Soil organic carbon (SOC) was significantly higher in the $\mathrm{O}$ horizon than in the A horizon for all four forest ecosystems (Table 1, P<0.05). Temperate region $(\mathrm{CBM})$ soils had higher SOC than subtropical region (JLM) soils from the same forest type and soil horizon $(\mathrm{P}<0.05)$. Both coniferous forests $(\mathrm{CF})$ had lower total soil $\mathrm{N}$ and a higher $\mathrm{C}$ : $\mathrm{N}$ ratio than the broadleaf forest $(\mathrm{BF})$ in their climatic zone $(\mathrm{P}<0.05)$, with the exception of $\mathrm{TN}$ in subtropical $\mathrm{O}$ horizons $(\mathrm{P}=0.327)$. Dissolved organic carbon (DOC) was higher in the $\mathrm{O}$ horizon than the A horizon of all four forest ecosystems $(\mathrm{P}<0.05)$. All soils were acidic $(\mathrm{pH} 4.2$ to 5.4$)$, with higher $\mathrm{pH}$ values in $\mathrm{BF}$ than in CF within a climatic zone except subtropical O-horizon soils $(\mathrm{P}=0.051)$.

\subsection{Soil neutral sugar content and composition}

Total neutral sugar content in different soil horizons of the four forest ecosystems ranged from 13.5 to $89.6 \mathrm{mg} \mathrm{g}^{-1}$ soil (Fig. 2A), with significantly higher sugar content in the $\mathrm{O}$ horizon $(\mathrm{P}<0.05)$. Total neutral sugar content was generally greater for temperate soils than subtropical soils for a given forest type and horizon $(\mathrm{P}<0.05)$, except A horizon soils in $\mathrm{CF}(\mathrm{P}=0.138)$. There were no consistent differences in total neutral sugar content between forest types. Neutral sugars made up $19.2 \%$ to $28.7 \%$ of total SOC content (Fig. 2B).

Abundances of individual soil neutral sugars $\left(\mathrm{mg} \mathrm{g}^{-1} \mathrm{C}\right)$ largely reflected the patterns observed for total soil neutral sugars, varying by climatic zone, forest type, and soil horizon (Fig. 3). Glucose was the most abundant soil neutral sugar, while ribose, fucose and rhamnose were least abundant. Contents of arabinose, xylose, galactose, and mannose in $\mathrm{O}$ horizons were generally higher than in corresponding $\mathrm{A}$ horizon $(\mathrm{P}<0.05)$, with the exceptions of mannose in temperate zone $\mathrm{BF}(\mathrm{P}=0.509)$ and galactose in subtropical zone $\mathrm{BF}(\mathrm{P}=0.227)$. Contents of these sugars in the temperate region were significantly different to that in the subtropical zone, within a forest type and soil horizon $(\mathrm{P}<0.05)$, except for mannose content in $\mathrm{BF} \mathrm{O}$ horizon 
$(\mathrm{P}=0.174)$. In the subtropical region, $\mathrm{CF}$ hexose concentrations in SOC were significantly higher than $\mathrm{BF}$, while in the temperate region concentrations of pentose were greater in the $\mathrm{BF}$ than the $\mathrm{CF}(\mathrm{P}<0.05)$.

BF litter had considerably higher pentose xylose concentrations and lower hexose mannose than CF litter, with more extreme differences between forest types in the subtropical region (Table 2). These litter differences were mirrored in the soil, where the proportion of hexoses, and thus the $(\mathrm{G}+\mathrm{M}) /(\mathrm{A}+\mathrm{X})$ ratio, was greater for $\mathrm{CF}$ than for $\mathrm{BF}$ (Fig. 4A, $\mathrm{P}<0.05)$. The $(\mathrm{G}+\mathrm{M}) /(\mathrm{A}+\mathrm{X})$ ratio of $\mathrm{CF}$ soils were different between climatic zones $(\mathrm{P}<0.05)$, but not for $\mathrm{BF} \mathrm{O}$ horizons $(\mathrm{P}=0.050)$ and $\mathrm{BF} \mathrm{A}$ horizons ( $\mathrm{P}=0.351)$ (Fig. 4A). In all cases, the A horizon soil had a higher $(\mathrm{G}+\mathrm{M}) /(\mathrm{A}+\mathrm{X})$ ratio than its corresponding $\mathrm{O}$ horizon $(\mathrm{P}<0.05)$. Increases in $\mathrm{BF}$ soil $(\mathrm{G}+\mathrm{M}) /(\mathrm{A}+\mathrm{X})$ ratios relative to litter inputs were significantly higher in the subtropical region; the reverse was true in $\mathrm{CF}$, with substantially larger increases in the temperate region (Fig. 4B). Compared with the increasing difference in $(\mathrm{G}+\mathrm{M}) /(\mathrm{A}+\mathrm{X})$ ratios for $\mathrm{O}$ horizon soils (relative to their respective plant litters), all $\mathrm{A}$ horizons exhibited a greater increase in the $(\mathrm{G}+\mathrm{M}) /(\mathrm{A}+\mathrm{X})$ ratios $(\mathrm{P}<0.05)$.

\subsection{Correlations between soil neutral sugars and environmental variables}

Most of the variability in soil neutral sugar compositions could be explained by RDA using edaphic and ecological grouping factors (Table 3). Ecological grouping factors alone explained nearly half of this variability, accounting for the bulk of the model's explanatory power. Soil horizon was the single most impactful factor, although forest type and climatic zone each made large individual contributions. TN was the strongest edaphic factor and was the only one approaching the ecological factors in relevance.

Environmental variables explained a total of $73.8 \%$ of variance in the soil neutral sugar composition matrix, with $64.6 \%$ of total variance captured in the first two RDA axes (Fig. 5). The soil horizon factor formed a strong gradient bisecting these two axes, with the $\mathrm{O}$ horizon associated with decreasing fucose and increasing arabinose, rhamnose, pH, TN and DOC (Fig. 5). Climatic zone and forest type jointly formed a single gradient which was largely perpendicular to the soil horizon gradient. The 
neutral sugar trends that align with each gradient were broadly present across all treatments, but were strongest in the visual outliers for each gradient. Arabinose contents were higher in all $\mathrm{O}$ horizons than their A horizons, but the difference was greatest in the temperate CF (Section 3.2, Fig. 3). Similarly, mannose was higher for $\mathrm{CF}$ than BF in both zones, while the climate zone effect was strongest in the CF (Fig. $3)$.

\section{Discussion}

\subsection{Effects of climatic zone and forest type on soil neutral sugar profiles}

Contrary to our expectations, soil neutral sugar profiles did not reflect different extents of microbial processing of SOC between the climatic zones (Fig. 4B). This was particularly noticeable in the subtropical $\mathrm{CF}$, where $(\mathrm{G}+\mathrm{M}) /(\mathrm{A}+\mathrm{X})$ ratios were only marginally different from those in the litter, contrasting with the substantial changes observed at all other sites. Differences in the neutral sugar contents of litter inputs were reflected in soils, particularly in the contrast between BF and CF in both climatic zones. We observed higher concentrations of hexoses, particularly mannose, in CF litter (Table 2), which is also demonstrated by strong relationships between soil mannose contents and forest type in the RDA results (Fig. 5). Our findings were in line with previously published observations of higher mannose content in coniferous litter than broadleaf litter (Berg and Mcclaugherty, 2008). This suggests that besides considerable resynthesis and/or recycling of soil hexoses by soil microbes (Amelung et al., 1999), unprocessed plant materials remained in the soil, making up a significant fraction of the total neutral sugar pool. Much higher $(\mathrm{G}+\mathrm{M}) /(\mathrm{A}+\mathrm{X})$ ratios have been reported for soils, including values up to 2.0 in pine forests (Folsom, 1974) and 2.3 in broadleaf forests (Nacro et al., 2005). Tanaka et al. (1990) even report ratios > 3 for biomass that has been entirely processed by soil bacteria. Thus, microbial processing could increase $(\mathrm{G}+\mathrm{M}) /(\mathrm{A}+\mathrm{X})$ ratios well above those found in $\mathrm{CF}$ litter, allowing this approach to capture microbial processing even in this case.

We found indirect evidence of greater microbial activity in the warmer and high-moisture zone. Both SOC and absolute total soil neutral sugar content were 
substantially lower at the subtropical sites (Fig. 2A, Table 1). While we did not quantify annual litter inputs in our study, prior work reports greater productivity at the subtropical site (Liao and Wang, 2000; Liu et al., 2009), and there is a broadly reported tendency toward greater litter fall in lower-latitude regions with high temperatures and rainfall (Bray and Gorham, 1964). It seems likely that the higher temperature increased microbial activity sufficiently to deplete SOC even with litter inputs at high moisture (Amelung et al., 1999), resulting in less neutral sugars left in the soil (Amelung et al., 1997). This inferred increased activity was not, however, evident in soil neutral sugar profiles.

The lack of a climatic zone effect on the $(\mathrm{G}+\mathrm{M}) /(\mathrm{A}+\mathrm{X})$ ratio was unexpected, but may indicate that inferring the extent of microbial SOC processing from soil neutral sugar profiles might not be purely straightforward. Although microbial products are thought to have a relatively higher $(\mathrm{G}+\mathrm{M}) /(\mathrm{A}+\mathrm{X})$ ratio (Oades, 1984), Gunina and Kuzyakov (2015) show that differences in soil neutral sugar ratios largely reflect the ratios of the litter inputs. Mathematically, microbial processing increases $(\mathrm{G}+\mathrm{M}) /(\mathrm{A}+\mathrm{X})$ ratios less in substrates with higher hexose contents, so in soils with weak microbial processing or high starting $(\mathrm{G}+\mathrm{M}) /(\mathrm{A}+\mathrm{X})$ ratios the marginal effects of microbial activity may be difficult to infer from soil neutral sugar profiles. An informative contrast is presented by Spielvogel et al. (2007), who observed increased $(\mathrm{G}+\mathrm{M}) /(\mathrm{A}+\mathrm{X})$ ratios in disturbed forest soils and attributed them to concomitant increases in temperature and moisture. Critically, this study reported lower soil $(\mathrm{G}+\mathrm{M}) /(\mathrm{A}+\mathrm{X})$ ratios $(<1.0)$, indicating limited microbial processing of SOC, and was conducted at a relatively high-latitude, high-elevation site which would be expected to have lower microbial activity. Neutral sugars may only reflect differences in microbial processing of SOC in environments where microbial processing is generally low. In our case, we were able to observe the overall effect of microbial processing by the increase in $(\mathrm{G}+\mathrm{M}) /(\mathrm{A}+\mathrm{M})$ ratios. However, differences in microbial activity may have been difficult to detect in the neutral sugar profiles, given the high starting levels of the ratios.

Alternatively, it is possible that the $(\mathrm{G}+\mathrm{M}) /(\mathrm{A}+\mathrm{X})$ ratio is more sensitive to 
microbial community composition than is typically thought. Differences in plant species, and in the properties of their litter and other nutrient outputs to the soil, could have helped shape distinct soil microbial communities (Hackl et al., 2005). For instance, $\mathrm{CF}$ soils tended to have higher $\mathrm{C}: \mathrm{N}$ ratios and lower $\mathrm{pH}$, potentially favoring fungi over bacteria (Högberg et al., 2007). Consequently, we detect that higher ratios in CF soils probably attributes to higher biomass of dominant soil fungi. In addition, some microbial groups contain considerable amounts of arabinose, as reported notably to exist in fungal hyphae (Gunina and Kuzyakov, 2015), which may directly influence the $(\mathrm{G}+\mathrm{M}) /(\mathrm{A}+\mathrm{X})$ ratio.

\subsection{Hexose abundance increases in soil and with depth}

Consistently across climatic zones and forest types, we observed greater $(\mathrm{G}+\mathrm{M}) /(\mathrm{A}+\mathrm{X})$ ratios in soil than in litter and in the A horizon than in the $\mathrm{O}$ horizon (Fig. 4, Table 2). The increased $(\mathrm{G}+\mathrm{M}) /(\mathrm{A}+\mathrm{X})$ ratio in the soil demonstrates the effect of microbial processing on neutral sugar profiles. The increase in relative hexose concentrations with depth in the soil profile has been previously observed across a variety of ecosystems (Folsom et al., 1974; Spielvogel et al., 2007), and has multiple possible explanations. Folsom (1974) attributed this effect to a greater abundance of incompletely decomposed plant material in the upper soil horizons. Another possibility is that microbial products, including microbially-derived neutral sugars, may be more amenable than plant materials to be physically stabilized by mineral interactions or incorporated into aggregates (Kiem and Kögel-Knabner, 2003; Rumpel et al., 2010).

We diagrammed the distribution pattern of pentoses and hexoses in plant litter and soil horizons for our four sites (Fig. 6). In both climatic zones, the O horizon was influenced by plant litter, reflecting the higher proportion of pentoses in BF litter and of hexoses in $\mathrm{CF}$ litter, which resulted in a higher proportion of pentoses in the BF O horizon and of hexoses in the CF O horizon. However, in mineral soils, we detected a higher proportion of hexoses than pentoses, in both BF and CF. This indicates that hexoses are distributed in mineral soil horizons at a higher proportion, most of which 
might be driven by microbes who decompose and mineralize plant litters, incorporate $\mathrm{C}$ into anabolic materials and deposit the microbial necromass. The faunal effect on neutral sugar distribution cannot be excluded since bioturbation is common in forest soils, unfortunately, we are unaware of any studies linking this process to soil neutral sugar profiles in forest ecosystems.

The consistently observed increase in the hexose to pentose ratios between the $\mathrm{O}$ and A horizons in four different forest ecosystems suggests a relative retention of microbial products with increasing soil depth and is consistent with previous study by Spielvogel et al. (2007). The mechanism underlying this phenomenon likely reflects multiple microbial processes including more extensive enzymatic degradation of plant $\mathrm{C}$ and recycling of this $\mathrm{C}$, which is ultimately stabilized as microbial biomass in deeper horizons (Guggenberger, 2005). Sugars interact with the soil mineral matrix, providing adhesion for the formation of soil aggregates, where they become occluded and are less likely to be decomposed by soil microbes (Oades, 1984; Puget et al., 1998; Spielvogel et al., 2007). Compared to plant-derived sugars, there is a greater affinity for sugars from microbial biomass or necromass which thus are more readily stabilized within the soil matrix (Rumpel et al., 2010; Spielvogel et al., 2007). This contributes to formation of stable micro-aggregates with huge implications for long-term soil C sequestration (Verchot et al., 2011). During this process, soil organic matter is formed not only by the degradation of plant-derived organic materials to small organic molecules, but also by the formation of new microbial compounds as $\mathrm{C}$ is assimilated into microbial biomass, released upon microbial death, and enters the soil organic matter pool. The awareness of a much higher microbial necromass contribution to stable SOC has been stimulated by empirical data and modeling simulation (Liang et al., 2011; Miltner et al., 2012; Schweigert et al., 2015; Simpson et al., 2007), but research on this aspect of soil organic matter formation is still lacking (Liang and Balser, 2011; Schaeffer et al., 2015).

In recent years, a novel conceptual framework termed the "microbial carbon pump" (MCP) has drawn increasing attention to the critical roles of marine microbes in producing recalcitrant dissolved organic matter and sequestrating it into the deep 
ocean (Jiao et al., 2010; Legendre et al., 2015). An analogue to the marine MCP is thought to operate in soils, where soil microbes incorporate biomass and residues into stable soil C pools (Liang and Balser, 2011). Under this framework, plant-derived C is converted to microbially-derived compounds, and it is this microbial $\mathrm{C}$ that is ultimately incorporated into the stable SOC pool (Benner, 2011; Liang and Balser, 2011; Liang and Balser, 2012). Consequently, the efficiency of the MCP determines a soil's capacity to retain organic $\mathrm{C}$, and the MCP model particularly highlights the importance of microbial processes in soil $\mathrm{C}$ storage. We posit that this model can serve as a conceptual basis for testing hypotheses regarding the actively cycling SOC pool and its underlying biogeochemical mechanisms. Our observations on the dynamics of pentoses and hexoses in soils support the existence of the MCP in a hierarchical manner. Considering that neutral sugars only serve as relatively labile $\mathrm{C}$ in soils, the transformation of those compounds may describe a mechanistic "front gate", through which labile $\mathrm{C}$ is able to be further recycled by microbes and ultimately incorporated into stable soil $\mathrm{C}$ pools.

\section{Conclusions}

Neutral sugars were investigated in natural forest ecosystems varying in vegetation type and climatic zone, in order to understand their distribution and interpretative potential. Soil $(\mathrm{G}+\mathrm{M}) /(\mathrm{A}+\mathrm{X})$ ratios were interpreted as an index to indicate the extent of microbial reworking of organic matter. These ratios reflected differences in plant litter neutral sugar profiles, but gave no evidence that microbial processing of SOC differed between climatic zones. In both regions, hexoses were proportionally more abundant in coniferous forest soils. Similar levels of total soil neutral sugar contents were found within a climatic zone, independent of vegetation type. Soil neutral sugar contents decreased from the $\mathrm{O}$ to the A horizon, while the $(\mathrm{G}+\mathrm{M}) /(\mathrm{A}+\mathrm{X})$ ratio increased with soil depth. This increase demonstrated the relative dominance of microbial products with increasing soil depth, highlighting the importance of microbially-mediated transformation of organic material in to the stable SOC pool. 


\section{Acknowledgement}

This study was financially supported by the National Science Foundation of China (No. 41471218 and 31160107), Strategic Priority Research Program of the Chinese Academy of Science, Grant No. XDB15010300, and U.S. DOE BER Office of Science DE-FC02-07ER64494. We also appreciate Drs. Xiangmin Fang and Zhen Bai for their great assistance of collecting Jiulian Mountain and Changbai Mountain soil and litter samples. 
Fig. 1. Geographic location of broadleaf forest and coniferous forest in temperate zone at Changbai Mountain (CBM) and in subtropical zone at Jiulian Mountain (JLM) in China.

Fig. 2. Soil total neutral sugar content (A) and ratio of soil neutral sugar carbon to soil organic carbon (B) in $\mathrm{O}$ and $\mathrm{A}$ horizon for broadleaf forest (BF) and coniferous forest $(\mathrm{CF})$ in temperate and subtropical zones in China. Error bars indicate the standard deviations $(\mathrm{N}=5)$.

Fig. 3. Concentration of eight soil monosaccharides in SOC in $\mathrm{O}$ and A horizon soils for broadleaf forest (BF) and coniferous forest (CF) in temperate and subtropical zones in China. Error bars indicate the standard deviations $(\mathrm{N}=5)$.

Fig. 4. The ratio of hexose to pentose $((\mathrm{G}+\mathrm{M}) /(\mathrm{A}+\mathrm{X}))(\mathrm{A})$ and the absolute change of the ratio relative to plant litter $(\mathrm{B})$ in $\mathrm{O}$ and $\mathrm{A}$ horizons for broadleaf forest $(\mathrm{BF})$ and coniferous forest $(\mathrm{CF})$ in temperate and subtropical zones in China. Error bars indicate the standard deviations $(\mathrm{N}=5)$.

Fig. 5. Redundancy analysis (RDA) between soil neutral sugar abundances (normalized to total soil carbon) and soil environmental variables in $\mathrm{O}$ and A horizons for broadleaf forest $(\mathrm{BF})$ and coniferous forest $(\mathrm{CF})$ in temperate zone at Changbai Mountain (CBM) and subtropical zones at Jiulian Mountain (JLM) in China. $\diamond$, samples of $\mathrm{O}$ horizon soil in $\mathrm{BF}, \mathrm{CBM}$; $\diamond$, samples of A horizon soil in BF, CBM; $\Delta$, samples of $\mathrm{O}$ horizon soil in $\mathrm{CF}, \mathrm{CBM}$; $\boldsymbol{\Delta}$, samples of A horizon soil in $\mathrm{CF}, \mathrm{CBM}$; , samples of $\mathrm{O}$ horizon soil in BF, JLM; $\bullet$, samples of A horizon soil in BF, JLM; $\square$, samples of O horizon in CF, JLM; $\mathbf{n}$, samples of A horizon soil in CF, JLM.

Fig. 6. A stylized illustration of the distribution in soil pentose and hexose contents in litter, $\mathrm{O}$ and $\mathrm{A}$ horizon soils for broadleaf forest $(\mathrm{BF})$ and coniferous forest $(\mathrm{CF})$ in temperate and subtropical zones in China. Pentagons indicate pentoses (the sum of arabinose and xylose), hexagons indicate hexoses (the sum of galactose and mannose). Figures adjacent to the dashed boxes are the total amount ( $\mathrm{mg} \mathrm{g}^{-1}$ sample) of pentoses (the sum of arabinose and xylose) and hexoses (the sum of galactose and mannose) for litter or soil samples in each forest ecosystem, while percentages in pentagons or hexagons are the proportions of the pentoses or hexoses in the total amount of these pentoses and hexoses for samples in each ecosystem. 


\section{References}

Amelung, W., Flach, K.W., Zech, W., 1999. Neutral and acidic sugars in particle-size fractions as influenced by climate. Soil Sci. Soc. Am. J. 63(4), 865-873.

Amelung, W., Zech, W., Flach, K.W., 1997. Climatic effects on soil organic matter composition in the Great Plains. Soil Sci. Soc. Am. J. 61(1), 115-123.

Balser, T.C., 2005. Humification. In: D. Hillel (Ed.), Encyclopedia of Soils in the Environment. Elsevier, Oxiford,UK, pp. 195-207.

Batjes, N.H., 1996. Total carbon and nitrogen in the soils of the world. Eur. J. Soil Sci. 47(2), 151-163.

Benner, R., 2011. Biosequestration of carbon by heterotrophic microorganisms. Nat. Rev. Microbiol. 9(1), 75.

Berg, B., Mcclaugherty, C., 2008. Plant Litter: Decomposition, Humus formation, Carbon sequestration. Springer Berlin. second ed. Springer, New York.

Bray, J.R., Gorham, E., 1964. Litter production in forests of the world. Adv. Ecol. Res. 2, 101-157.

Cheshire, M.V., 1979. Nature and Origin of Carbohydrates in Soils. Academic Press, London.

Dray, S., Legendre, P., Blanchet, F.G., 2013. packfor: forward selection with permutation. R package version 0.0-8/r99.

Eriksson, K.E., Blanchette, R.A., Ander, P., 1990. Microbial and Enzymatic Degradation of Wood and Wood Components. Springer, Berlin.

Folsom, B.L., Wagner, G.H., Scrivner, C.L., 1974. Comparison of soil carbohydrate in several prairie and forest soil by gas-liquid-chromatography. Soil Sci. Soc. Am. J. 38(2), 305-309.

Guggenberger, G., 2005. Humification and mineralization in soils. In: Warma.A, F. Buscot (Eds.), Soil Biol. Springer, Berlin, pp. 85-106.

Guggenberger, G., Christensen, B.T., Zech, W., 1994. Land-use effects on the composition of organic matter in particle-size separates of soil: I. lignin and carbohydrate signature. Eur. J. Soil Sci. 45(4), 449-458.

Gunina, A., Kuzyakov, Y., 2015. Sugars in soil and sweets for microorganisms: review of origin, content, composition and fate. Soil Biol. Biochem. 90, 87-100.

Högberg, M.N., Högberg, P., Myrold, D.D., 2007. Is microbial community composition in boreal forest soils determined by $\mathrm{pH}, \mathrm{C}$-to-N ratio, the trees, or all three? Oecologia 150(4), 590-601.

Hackl, E., Pfeffer, M., Donat, C., Bachmann, G., Zechmeister-Boltenstern, S., 2005. Composition of the microbial communities in the mineral soil under different types of natural forest. Soil Biol. Biochem. 37(4), 661-671.

Haider, K., 1992. Problems related to the humification processes in soils of temperate climates. Soil Biochem. 7, 55-94.

Jiao, N.Z., Herndl, G.J., Hansell, D.A., Benner, R., Kattner, G., Wilhelm, S.W., Kirchman, D.L., Weinbauer, M.G., Luo, T.W., Chen, F., 2010. Microbial production of recalcitrant dissolved organic matter: long-term carbon storage in the global ocean. Nat. Rev. Microbiol. 8(8), 593-599.

Jolivet, C., Angers, D.A., Chantigny, M.H., Andreux, F., Arrouays, D., 2006. Carbohydrate dynamics in particle-size fractions of sandy spodosols following forest conversion to maize cropping. Soil Biol. Biochem. 38(9), 2834-2842.

Kögel-Knabner, I., 2002. The macromolecular organic composition of plant and microbial residues as inputs to soil organic matter. Soil Biol. Biochem. 34(2), 139-162.

Kiem, R., Kögel-Knabner, I., 2003. Contribution of lignin and polysaccharides to the refractory carbon pool in C-depleted arable soils. Soil Biol. Biochem. 35(1), 101-118.

Legendre, L., Rivkin, R.B., Weinbauer, M.G., Guidi, L., Uitz, J., 2015. The microbial carbon pump concept: Potential biogeochemical significance in the globally changing ocean. Prog. Oceanogr. 134, 432-450.

Liang, C., Balser, T.C., 2011. Microbial production of recalcitrant organic matter in global soils: implications for productivity and climate policy. Nat. Rev. Microbiol. 9(1), 75-75.

Liang, C., Balser, T.C., 2012. Warming and nitrogen deposition lessen microbial residue contribution to soil carbon pool. Nat. commun. 3, 1222.

Liang, C., Cheng, G., Wixon, D.L., Balser, T.C., 2011. An Absorbing Markov Chain approach to understanding the microbial role in soil carbon stabilization. Biogeochemistry 106(3), 303-309.

Liao, J., Wang, X.G., 2000. Researches on forest litter production. JiangXi For. Sci. Technol. 1, 31-34.

Liu, Y., Han, S.J., Lin, L., 2009. Dynamic characteristics of litterfalls in four forest types of Changbai 
Mountains, China. Chin. J. Ecol. 28, 7-11.

Miltner, A., Bombach, P., Schmidt-Brücken, B., Kastner, M., 2012. SOM genesis: microbial biomass as a significant source. Biogeochemistry 111(1-3), 41-55.

Murata, T., Tanaka, H., Yasue, S., Hamada, R., Sakagami, K., Kurokawa, Y., 1999. Seasonal variations in soil microbial biomass content and soil neutral sugar composition in grassland in the Japanese Temperate Zone. Appl. Soil Ecol. 11(2), 253-259.

Murty, D., Kirschbaum, M.U.F., Mcmurtrie, R.E., Mcgilvray, H., 2002. Does conversion of forest to agricultural land change soil carbon and nitrogen? A review of the literature. Glob. Chang. Biol. 8(2), 105-123.

Nacro, H.B., Larré-Larrouy, M.C., Feller, C., Abbadie, L., 2005. Hydrolysable carbohydrate in tropical soils under adjacent forest and savanna vegetation in Lamto, Côte d'Ivoire. Soil Res. 43(6), 705-711.

Navarrete, I.A., Tsutsuki, K., 2008. Land-use impact on soil carbon, nitrogen, neutral sugar composition and related chemical properties in a degraded Ultisol in Leyte, Philippines. Soil Sci. Plant Nutr. 54(3), 321-331.

Oades, J.M., 1984. Soil organic matter and structural stability: mechanisms and implications for management. Plant Soil 76(1-3), 319-337.

Oksanen, J., Blanchet, F.G., Kindt, R., Legendre, P., Minchin, P.R., O’Hara, R.B., Simpson, G.L., Solymos, P., Stevens, M.H.H., Wagner, H., 2015. vegan: community ecology package. R package version 2.0-10. 2013.

Peres-Neto, P.R., Legendre, P., Dray, S., Borcard, D., 2006. Variation partitioning of species data matrices: estimation and comparison of fractions. Ecology 87(10), 2614-2625.

Puget, P., Angers, D.A., Chenu, C., 1998. Nature of carbohydrates associated with water-stable aggregates of two cultivated soils. Soil Biol. Biochem. 31(1), 55-63.

Rumpel, C., Eusterhues, K., Kögel-Knabner, I., 2010. Non-cellulosic neutral sugar contribution to mineral associated organic matter in top-and subsoil horizons of two acid forest soils. Soil Biol. Biochem. 42(2), 379-382.

Schaeffer, A., Nannipieri, P., Kästner, M., Schmidt, B., Botterweck, J., 2015. From humic substances to soil organic matter-microbial contributions. In honour of Konrad Haider and James P. Martin for their outstanding research contribution to soil science. J. Soil. Sediment. 15(9), 1865-1881.

Schimel, J.P., Schaeffer, S.M., 2012. Microbial control over carbon cycling in soil. Front. Microbiol. 3, 155-165.

Schlesinger, W.H., Bernhardt, E.S., 2013. Biogeochemistry: An Analysis of Global Change. third ed. Academic press, London.

Schmidt, J., Schulz, E., Michalzik, B., Buscot, F., Gutknecht, J.L.M., 2015. Carbon input and crop-related changes in microbial biomarker levels strongly affect the turnover and composition of soil organic carbon. Soil Biol. Biochem. 85, 39-50.

Schweigert, M., Herrmann, S., Miltner, A., Fester, T., Kästner, M., 2015. Fate of ectomycorrhizal fungal biomass in a soil bioreactor system and its contribution to soil organic matter formation. Soil Biol. Biochem. 88, 120-127.

Sedjo, R.A., 1993. The carbon cycle and global forest ecosystem. Water Air Soil Pollut. 70(1-4), 295-307.

Simpson, A.J., Simpson, M.J., Smith, E., Kelleher, B.P., 2007. Microbially derived inputs to soil organic matter: are current estimates too low? Environ. Sci. Technol. 41(23), 8070-8076.

Spielvogel, S., Prietzel, J., Kögel-Knabner, I., 2007. Changes of lignin phenols and neutral sugars in different soil types of a high-elevation forest ecosystem 25 years after forest dieback. Soil Biol. Biochem. 39(2), 655-668.

Tanaka, H., Hamada, R., Kondoh, A., Sakagami, K., 1990. Determination of component sugars in soil organic matter by HPLC. Zentralbl. Mikrobiol. 145(8), 621-628.

Team, R.D.C., 2015. R: A language and environment for statistical computing. Vienna, Austria: R Foundation for Statistical Computing;. http:// www. R-project. org.

Verchot, L.V., Dutaur, L., Shepherd, K.D., Albrecht, A., 2011. Organic matter stabilization in soil aggregates: understanding the biogeochemical mechanisms that determine the fate of carbon inputs in soils. Geoderma 161(3), 182-193.

WRB, I.W.G., 2014. World Reference Base for Soil Resources 2014: International soil classification system for naming soils and creating legends for soil maps. No. 106, FAO, Rome. 
Xie, H.T., Li, J.W., Zhu, P., Peng, C., Wang, J.K., He, H.B., Zhang, X.D., 2014. Long-term manure amendments enhance neutral sugar accumulation in bulk soil and particulate organic matter in a Mollisol. Soil Biol. Biochem. 78, 45-53.

Zhang, W., He, H.B., Zhang, X.D., 2007. Determination of neutral sugars in soil by capillary gas chromatography after derivatization to aldononitrile acetates. Soil Biol. Biochem. 39(10), 2665-2669.

Zhu, B., Wang, X.P., Fang, J.Y., Piao, S.L., Shen, H.H., Zhao, S.Q., Peng, C.H., 2010. Altitudinal changes in carbon storage of temperate forests on Mt Changbai, Northeast China. J. Plant Res. 123(4), 439-452. 
Table 1. Physiochemical properties of $O$ and $A$ horizon soils in the four different forest ecosystems. Mean and standard deviation were shown $(\mathrm{N}=5)$.

\begin{tabular}{|c|c|c|c|c|c|c|c|c|c|}
\hline \multirow{2}{*}{$\begin{array}{l}\text { Climatic } \\
\text { zone }\end{array}$} & \multirow{2}{*}{$\begin{array}{l}\text { Geographic } \\
\text { places }\end{array}$} & \multirow{2}{*}{$\begin{array}{l}\text { Forest } \\
\text { type }\end{array}$} & \multirow{2}{*}{$\begin{array}{l}\text { Soil } \\
\text { horizon }\end{array}$} & \multirow{2}{*}{$\frac{\text { Depth }}{\mathrm{cm}}$} & SOC & DOC & $\mathrm{TN}$ & \multirow{2}{*}{$\mathrm{C} / \mathrm{N}$} & \multirow{2}{*}{$\mathrm{pH}$} \\
\hline & & & & & $\mathrm{mg} \mathrm{g}^{-1}$ soil & & & & \\
\hline \multirow[t]{4}{*}{ Temperate } & $\mathrm{CBM}$ & $\mathrm{BF}$ & $\mathrm{O}$ & 3 & $326.1 \pm 22.8$ & $2.8 \pm 1.0$ & $14.4 \pm 1.1$ & 22.6 & 5.4 \\
\hline & & & A & 13 & $202.6 \pm 34.0$ & $0.9 \pm 0.2$ & $12.0 \pm 2.0$ & 16.9 & 5.1 \\
\hline & & $\mathrm{CF}$ & $\mathrm{O}$ & 4 & $329.9 \pm 16.3$ & $3.9 \pm 0.5$ & $12.2 \pm 0.8$ & 27.1 & 4.4 \\
\hline & & & $\mathrm{A}$ & 10 & $92.8 \pm 22.9$ & $0.7 \pm 0.1$ & $3.5 \pm 0.7$ & 26.2 & 4.3 \\
\hline \multirow[t]{4}{*}{ Subtropical } & JLM & $\mathrm{BF}$ & $\mathrm{O}$ & 2 & $133.3 \pm 22.7$ & $2.1 \pm 0.3$ & $6.7 \pm 0.9$ & 19.7 & 4.9 \\
\hline & & & A & 15 & $74.0 \pm 14.3$ & $0.6 \pm 0.1$ & $4.3 \pm 0.6$ & 17.3 & 4.5 \\
\hline & & $\mathrm{CF}$ & $\mathrm{O}$ & 2 & $147.3 \pm 42.0$ & $1.4 \pm 0.4$ & $5.9 \pm 1.6$ & 25.2 & 4.5 \\
\hline & & & A & 15 & $53.6 \pm 10.7$ & $0.7 \pm 0.1$ & $2.3 \pm 0.5$ & 20.7 & 4.2 \\
\hline
\end{tabular}

CBM: Changbai Mountain; JLM: Jiulian Mountain; BF: broadleaf forest; CF: coniferous forest.

SOC: soil organic carbon; DOC: dissolved organic carbon; TN: total nitrogen. 
Table 2. Characterization of plant litter in the four different forest ecosystems.

\begin{tabular}{|c|c|c|c|c|c|c|c|c|c|c|c|c|c|}
\hline \multirow{2}{*}{$\begin{array}{l}\text { Climatic } \\
\text { zone }\end{array}$} & \multirow{2}{*}{$\begin{array}{l}\text { Forest } \\
\text { type }\end{array}$} & \multirow[t]{2}{*}{ Dominant species } & \multirow{2}{*}{$\begin{array}{l}\text { Litter } \\
\mathrm{C} / \mathrm{N}\end{array}$} & Ribose & Rhamnose & Arabinose & Xylose & Fucose & Mannose & Glucose & Galactose & $\begin{array}{l}\text { Total } \\
\text { sugars }\end{array}$ & \multirow[t]{2}{*}{$(\mathrm{G}+\mathrm{M}) /(\mathrm{A}+\mathrm{X})$} \\
\hline & & & & \multicolumn{9}{|c|}{$\mathrm{mg} \mathrm{g}^{-1}$ litter } & \\
\hline \multirow[t]{2}{*}{ Temperate } & $\mathrm{BF}$ & Tilia amurensis Rupr. & 43.5 & 0.50 & 28.16 & 30.36 & 25.63 & 2.04 & 6.10 & 52.21 & 24.52 & 169.51 & 0.55 \\
\hline & $\mathrm{CF}$ & $\begin{array}{l}\text { Larix olgensis var. changpaiensis } \\
\text { A. Henry }\end{array}$ & 91.9 & 0.31 & 6.14 & 33.03 & 18.25 & 1.38 & 27.22 & 48.13 & 23.20 & 157.67 & 0.98 \\
\hline \multirow[t]{2}{*}{ Subtropical } & $\mathrm{BF}$ & Castanopsis carlesii Hemsl. & 32.6 & 0.28 & 11.60 & 23.81 & 47.11 & 1.58 & 3.07 & 38.14 & 21.15 & 146.74 & 0.34 \\
\hline & $\mathrm{CF}$ & Pinus massoniana Lamb. & 77.0 & 0.33 & 7.08 & 23.02 & 18.29 & 0.99 & 36.73 & 41.73 & 24.34 & 152.51 & 1.48 \\
\hline
\end{tabular}

BF: broadleaf forest; $\mathrm{CF}$ : coniferous forest.

$(\mathrm{G}+\mathrm{M}) /(\mathrm{A}+\mathrm{X})$ : the ratio of hexose (galactose and mannose) to pentose (arabinose and xylose). 
Table 3. Percentage of variance of edaphic and ecological grouping variables in explaining soil neutral sugar composition variation of the four forest ecosystems in redundancy analysis and associated P-value.

\begin{tabular}{lll}
\hline \multicolumn{1}{c}{ Variables } & \multicolumn{1}{c}{ Adjust $\mathbf{R}^{\mathbf{2}}$} & \multicolumn{1}{c}{$\mathbf{P}$} \\
\hline Edaphic factors & & \\
TN & $11.94 \%$ & 0.0001 \\
pH & $4.95 \%$ & 0.0006 \\
DOC & $0.19 \%$ & 0.0293 \\
SOC & 0 & 0.365 \\
Ecological grouping factors & & \\
Soil horizon & $22.93 \%$ & 0.0001 \\
Forest type & $17.99 \%$ & 0.0001 \\
Climatic zone & $14.04 \%$ & 0.0002 \\
Groups of variables & & \\
Edaphic (TN + pH + DOC) & $18.79 \%$ & 0.001 \\
Ecological grouping (Soil horizon + Climatic zone + Forest type) & $46.35 \%$ & 0.001 \\
Edaphic + Ecological grouping & $73.77 \%$ & 0.001 \\
\hline
\end{tabular}

TN: total nitrogen; SOC: soil organic carbon; DOC: dissolved organic carbon.

$\mathrm{P}$ is P-values from Monte Carlo permutation test. 


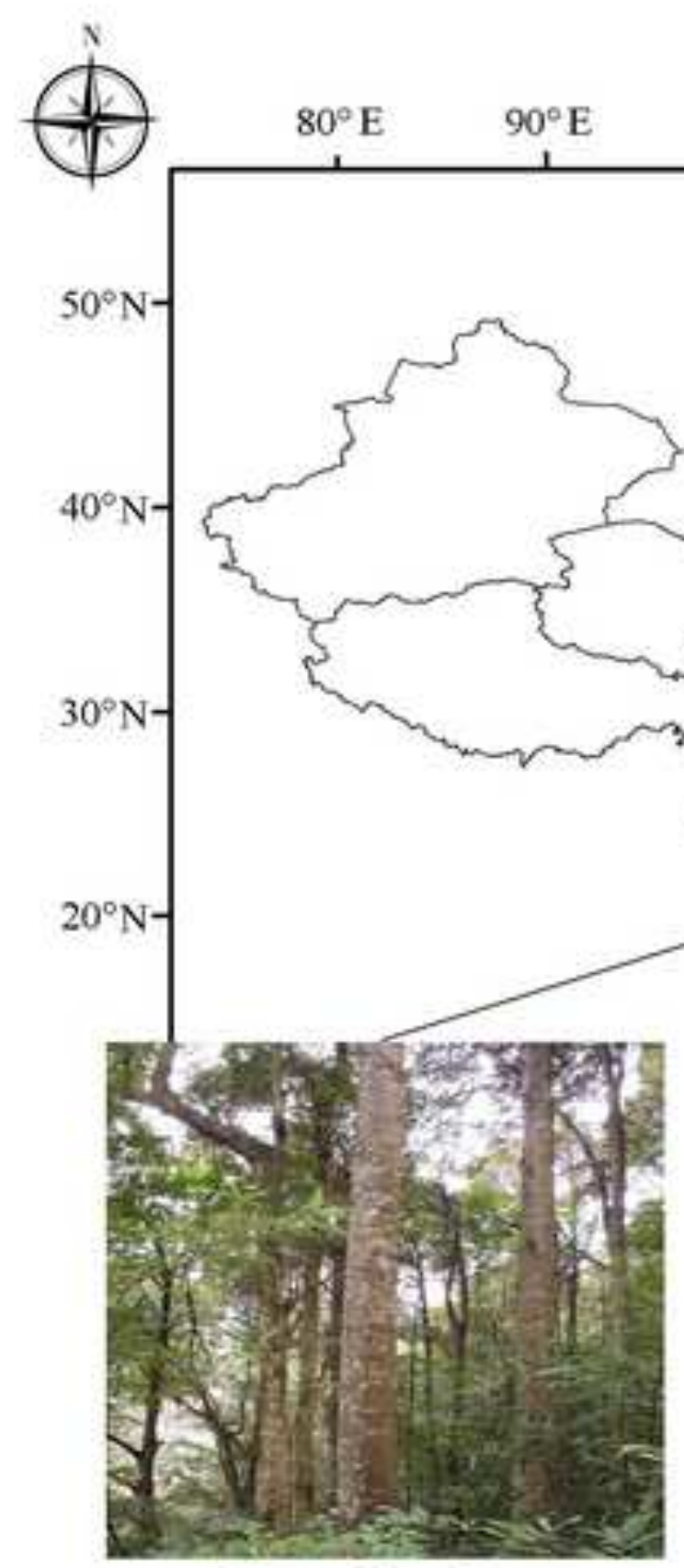

Broadleaf $100^{\circ} \mathrm{E} \quad 110^{\circ} \mathrm{E}$

$120^{\circ} \mathrm{E}$

$130^{\circ} \mathrm{E}$
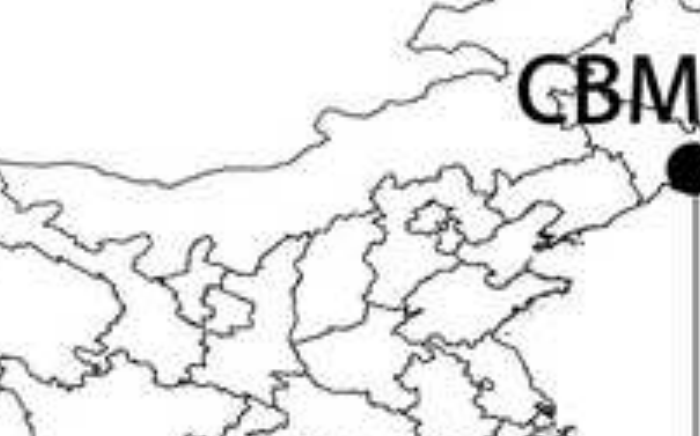

पर?

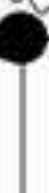

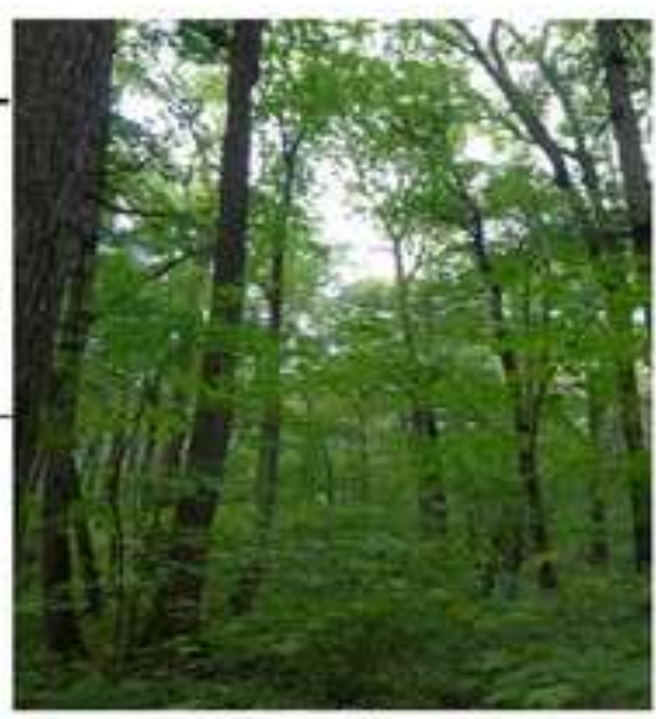

Coniferous
Broadleaf

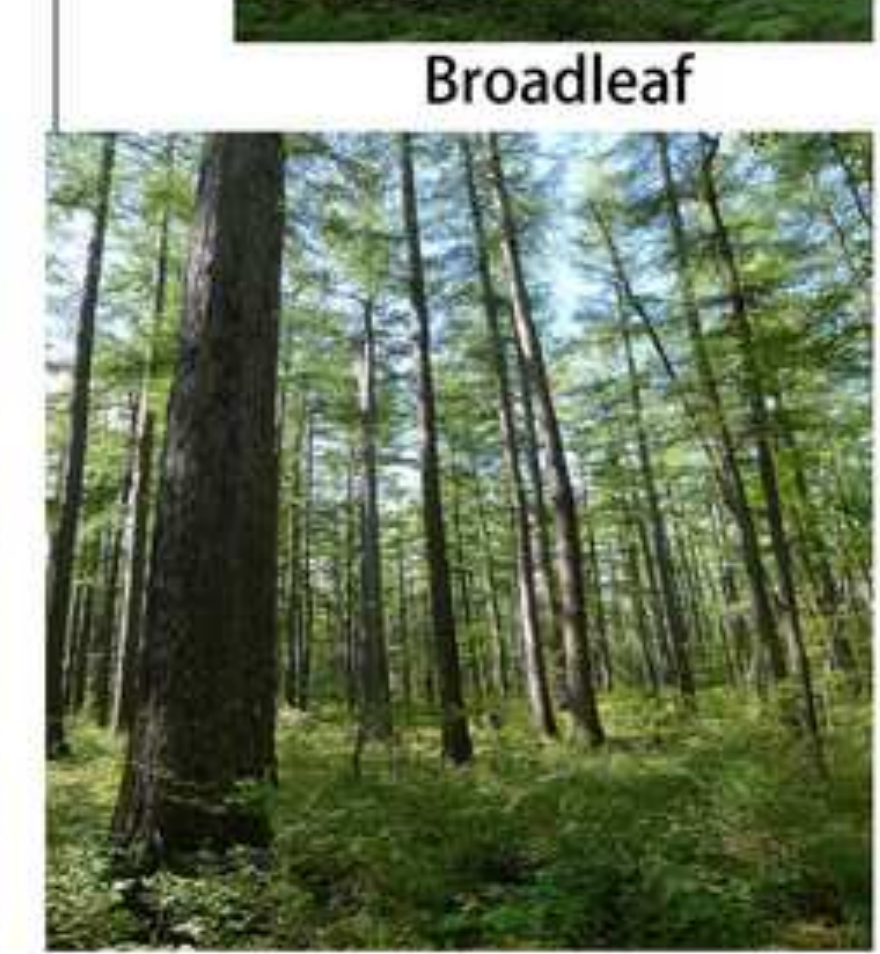

Coniferous 


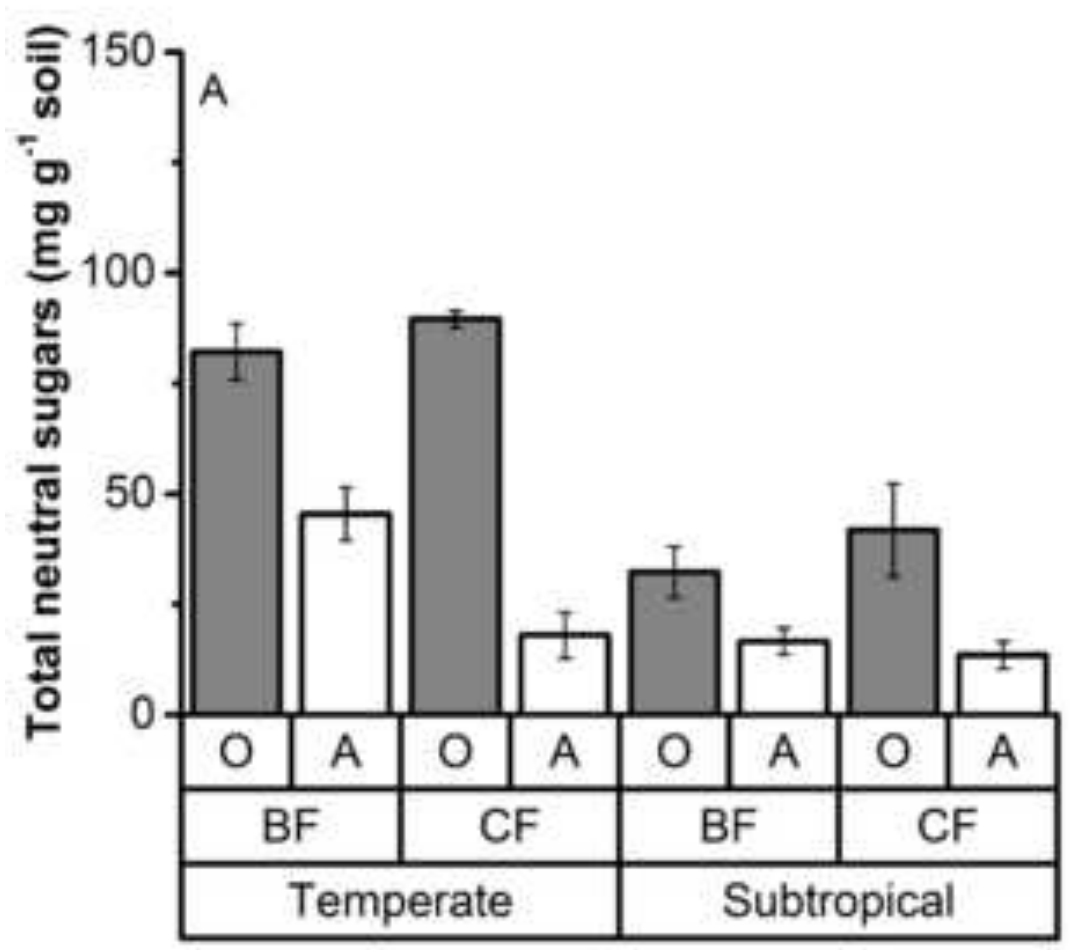

Factor

Climatic zone (CZ)

Forest type (FT)

Soil horizon $(\mathrm{SH})$

$\mathrm{CZ} \times F \mathrm{~T}$

$\mathrm{CZ} \times \mathrm{SH}$

$\mathrm{FT} \times \mathrm{SH}$

$\mathrm{CZ} \times \mathrm{FT} \times \mathrm{SH}$

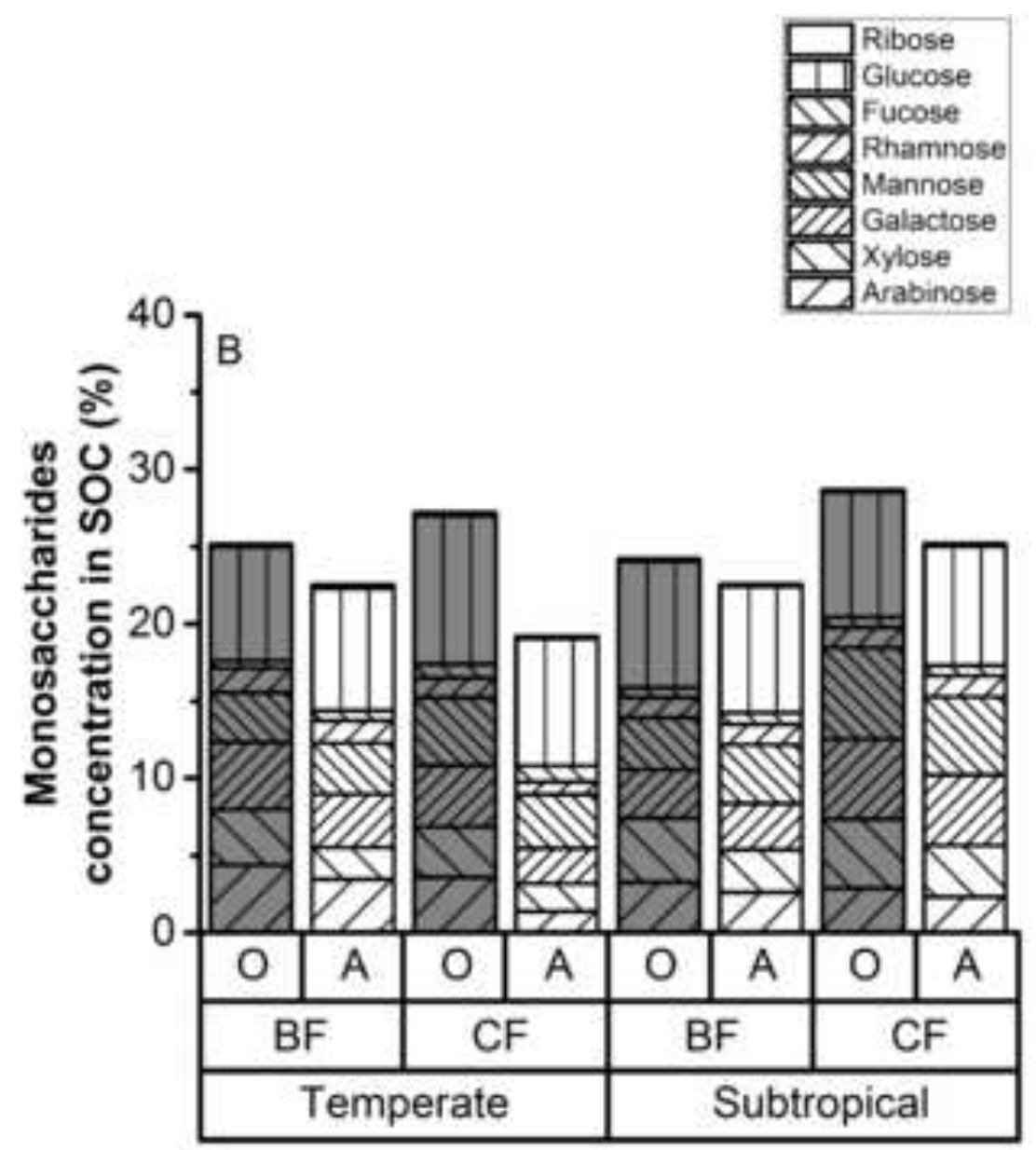

Significance

total neutral sugars total sugar concentrations in SOC

$\begin{array}{ll}* * * & * * \\ n . S . & * \\ * * * & * * * \\ * * * & * * * \\ * * * & * * * \\ * * * & * *\end{array}$




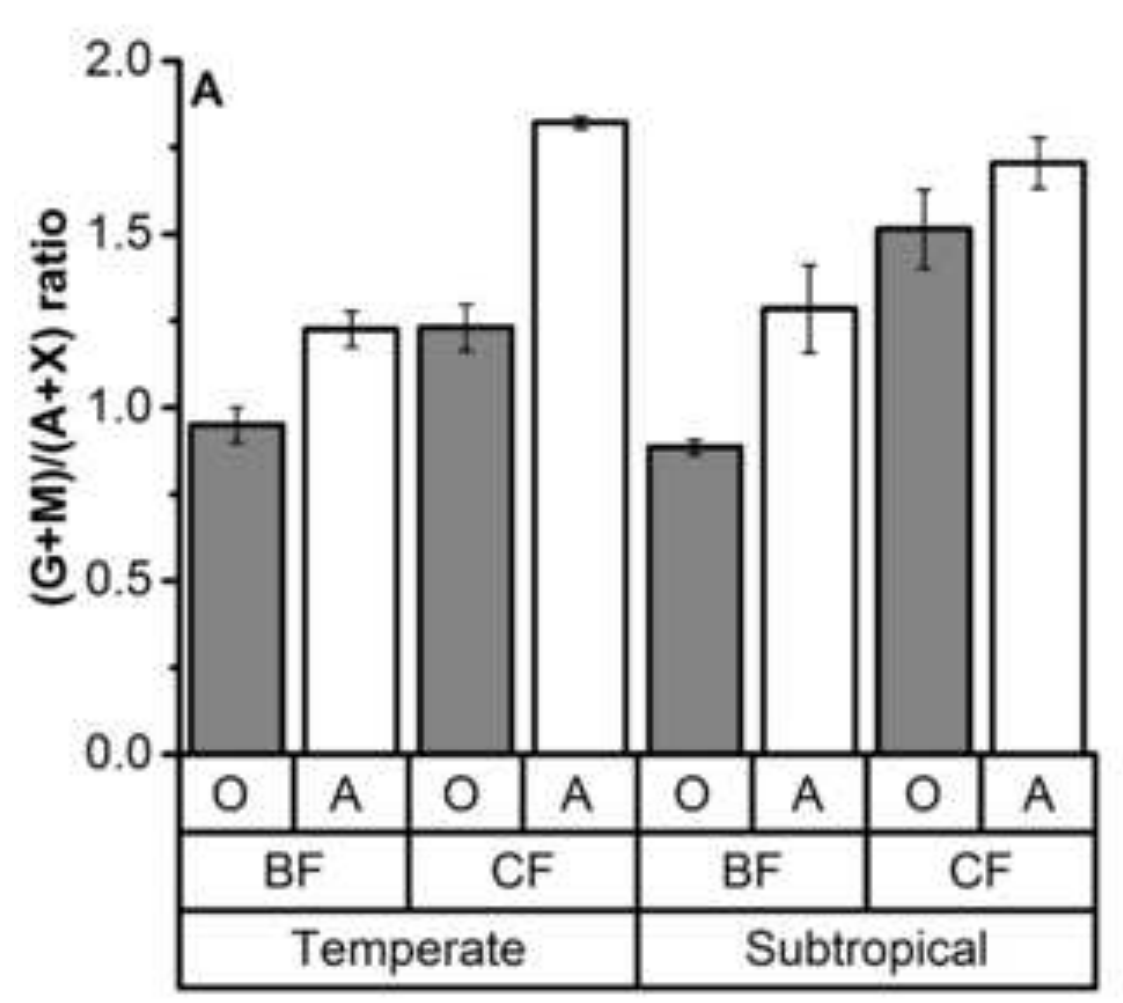

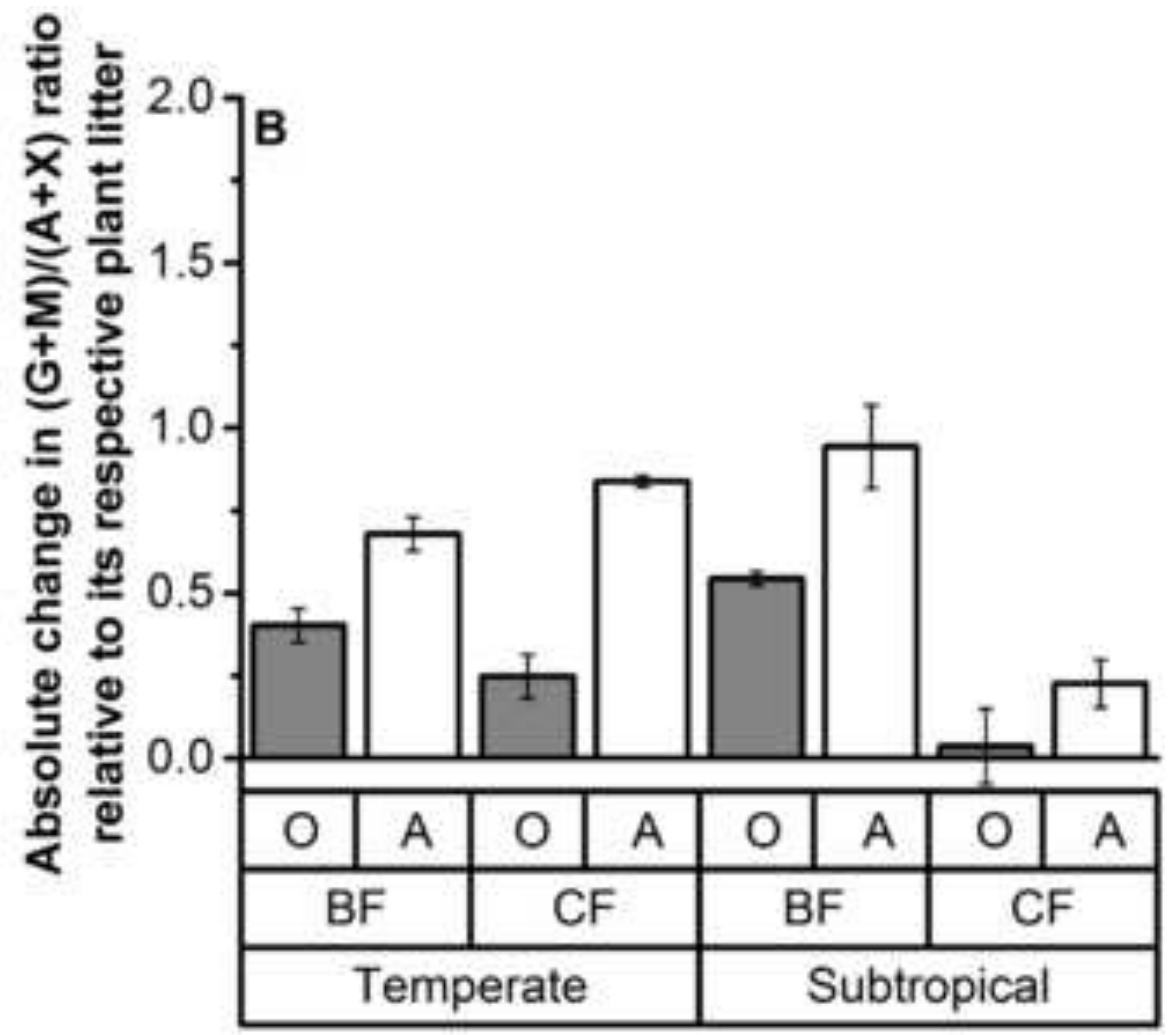

Significance

Factor

$(\mathrm{G}+\mathrm{M}) /(\mathrm{A}+\mathrm{X})$ ratio

Absolute change in $(\mathrm{G}+\mathrm{M}) /(\mathrm{A}+\mathrm{X})$ ratio relative to its respective plant litter

n.s.

$* * *$

***

n.s.

$*$

n.s.

***

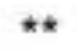

**

$\star \star \star$

***

t*

n.s.

*** 


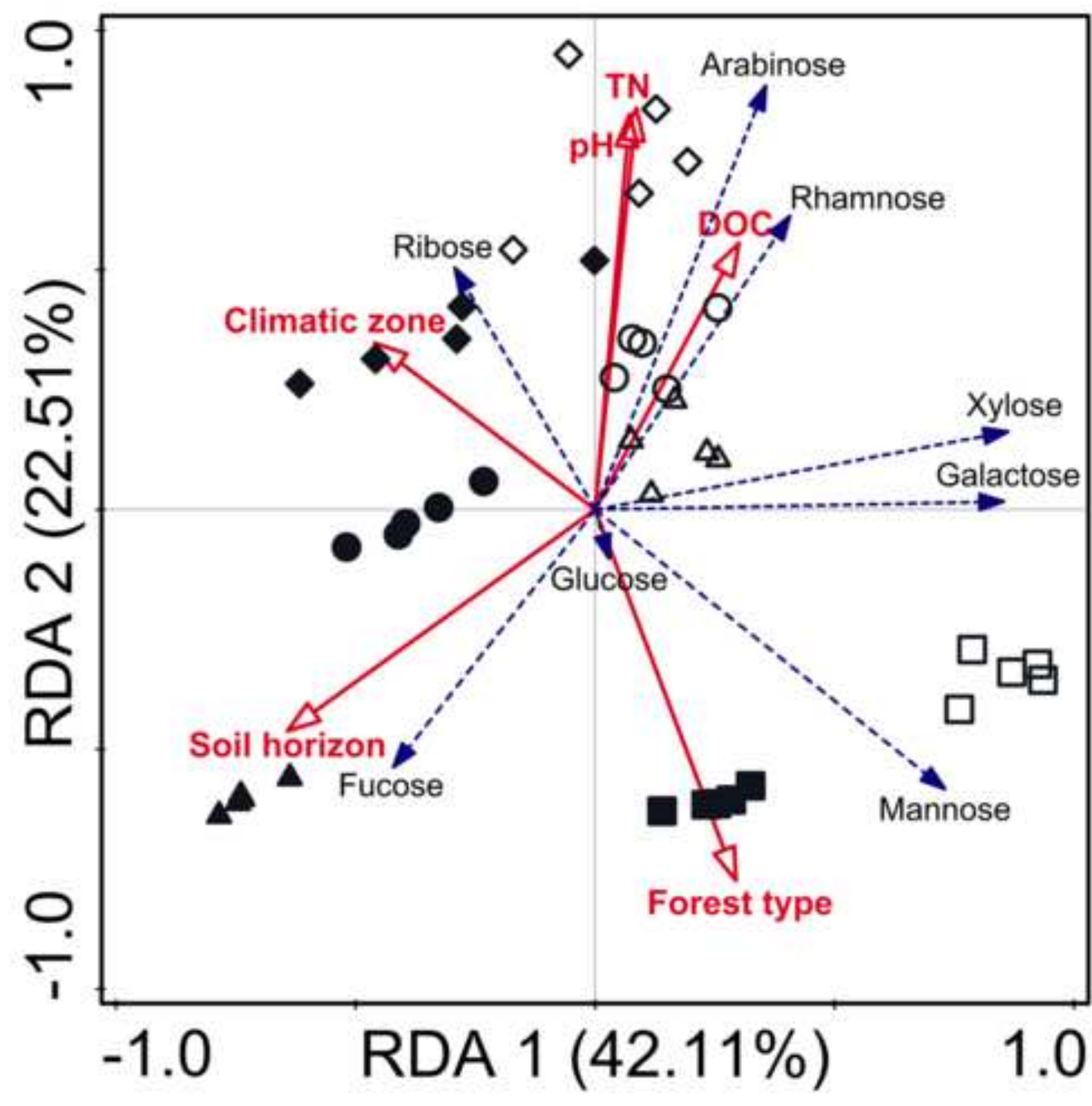

$\diamond \mathrm{O}$ horizon in $\mathrm{BF}$ of CBM

- A horizon in BF of CBM

$\triangle O$ horizon in CF of CBM

$\triangle$ A horizon in CF of CBM

O O horizon in BF of JLM

- A horizon in BF of JLM

$\square$ O horizon in CF of JLM

- A horizon in CF of JLM 

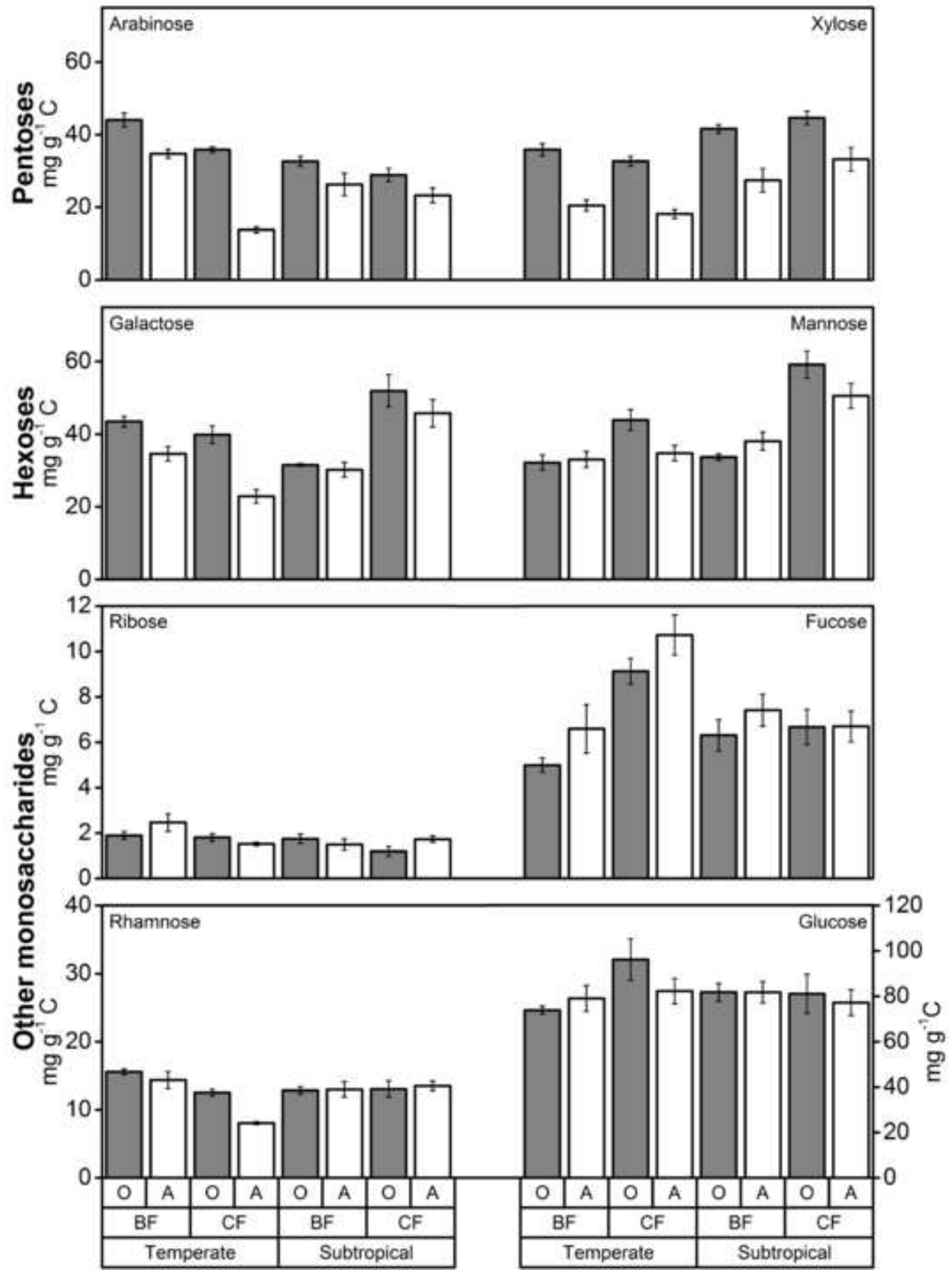


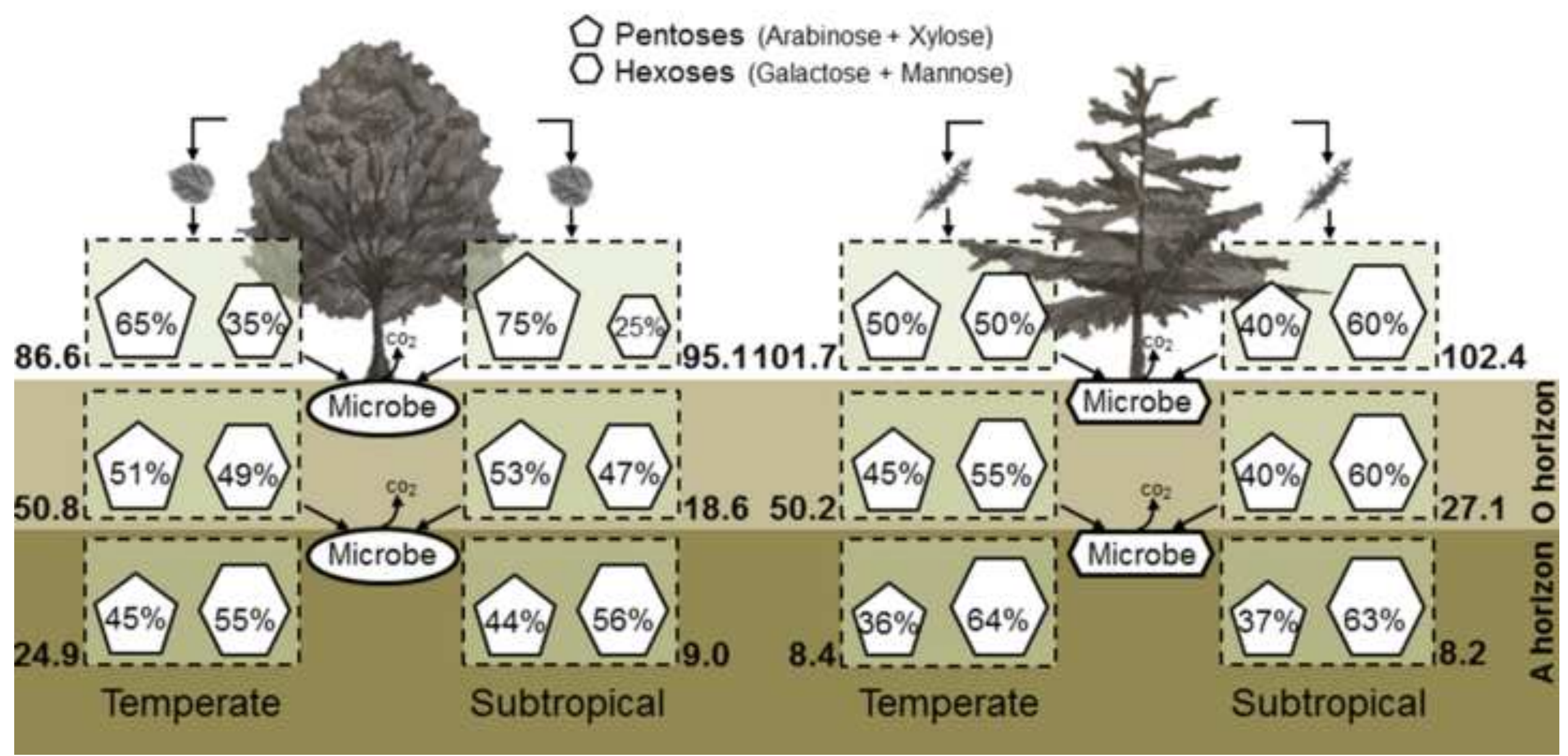

